\title{
KRYTYKA GLOBALIZACJI I AMERYKANIZACJI KULTURY EUROPEJSKIEJ W TWÓRCZOŚCI KATHRIN RÖGGLI
}

SŁOWA KLUCZOWE: globalizacja, amerykanizacja, literatura austriacka XX w., Kathrin Röggla

Centralnym aspektem w twórczości Kathrin Röggli jest ukazanie w krytycznym świetle wybranych aspektów globalizacji, która wiąże się również z procesem amerykanizacji, ponieważ językiem globalizacji we wszystkich dziedzinach (od gospodarki do nauki i kultury) stat się język angielski [Żmigrodzki, 2011, s. 177]. Oba zjawiska występują na co najmniej kilku płaszczyznach: w sferze ekonomicznej, informacyjnej, socjalnej, polityce i kulturze [por. Jacko, 2008, s. 261-277].

Do publikacji naukowych, które w zwięzły sposób omawiają pojęcie ,globalizacji”, należy Politologia. Przewodnik encyklopedyczny. Jego autorzy sformułowali następującą definicję tego zjawiska:

globalizacja — charakterystyczne i dominujące w końcu XX i na początku XXI w. tendencje w światowej ekonomii, polityce, demografii, życiu społecznym i kulturze, polegające na rozprzestrzenianiu się analogicznych zjawisk, niezależnie od kontekstu geograficznego i stopnia gospodarczego zaawansowania danego regionu.

[Politologia. Przewodnik..., 2008, s. 67]

W większości opracowań pojęcie „globalizacji” definiuje się jednak w kontekście problemów gospodarczych:

Robert Reich uważa, że pierwszy etap globalizacji rozpoczął się w chwili, gdy nastąpił koniec gospodarek narodowych (zaspokajanie własnych potrzeb i kierowanie na rynki zewnętrzne tylko nadwyżek towarowych). Na drugim etapie przedsiębiorstwa i koncerny zaczęły eksportować fabryki do krajów, w których siła robocza i surowce są tanie, a zyski duże. Trzeci etap charakteryzuje się przeniesieniem poważnej części produkcji do Ameryki Południowej, Chin i Afryki Południowej.

[Żmigrodzki, 2011, s. 177]

Według Robertsona natomiast zjawisko globalizacji polega m.in. na:

powstaniu relacji gospodarczych, które przekraczają granice państwowe. Największe korporacje działają na terenie kilku krajów, produkując komponenty, sprzedając towary i zdobywając fundusze na działalność w państwach na całym świecie (...). Gospodarki różnych 
krajów stały się współzależne: spadek produkcji w jednym rejonie świata może wpłynąć na sytuację na rynku geograficznie niezwykle odległym.

[Robertson, 2009, s. 129]

Zdaniem autora, charakterystyczny jest również:

gwałtowny rozwój instytucji ponadnarodowych oraz zjawisko zanikania tożsamości narodowej pośród świetnie wykształconej elity międzynarodowej gospodarki i polityki.

[Tamże, s. 129-130]

Niektóre opracowania podkreślają jednak, że fenomen globalizacji dotyczy nie tylko kwestii gospodarczych, ale także determinuje życie społeczne i polityczne oraz rozwój kultury ${ }^{1}$. Zdania są podzielone co do tego, kiedy datują się początki procesu globalizacji: Niektórzy (np. noblista Armatys K. Sen) traktuja globalizację jako proces historyczny, rozwijający się od najdawniejszych czasów. Większość uczonych nie podziela jednak tego poglądu wskazując, że jest to zjawisko należace do XX i XXI wieku. [Żmigrodzki, 2011, s. 178].

Z procesem globalizacji wiąże się ściśle również amerykanizacja kultury europejskiej, która często bywa z nią utożsamiana. Ów fakt podkreślają autorzy Encyklopedii politologii:

$\mathrm{Na}$ szczycie globalnej hierarchii władzy bezspornie stoją Stany Zjednoczone Ameryki i dlatego często globalizacja jest postrzegana jako synonim amerykanizacji. Dominacja USA widoczna jest wyraźnie w sferze finansów, handlu światowego, cyberprzestrzeni, korporacji transnarodowych, militarnej i bezpieczeństwa narodowego.

[Żmigrodzki, 2011, s. 178]

Słownik Wyrazów Obcych pod redakcją Elżbiety Sobol podaje następującą definicję ,,amerykanizacji”: wprowadzenie wzorów, zwyczajów amerykańskich, amerykańskiego stylu życia; wywieranie wpływu na kogoś, by nabrat cech Amerykanina, stat

${ }^{1}$ Autorzy Encyklopedii politologii stwierdzają: G.[lobalizacja] może być postrzegana jako zespót sprzężeń między tadami: ekonomicznym, prawnym, technicznym, moralnym, naukowym $i$ artystycznym, których celem jest dażenie do ujednolicenia podstaw życia społeczno-ekonomicznego i politycznego świata (W. Aniol). G.[lobalizacja] oznacza także ,sytuację tączenia się przestrzennego państw, wymuszona koniecznościa”" (B. Rosomond). Wedtug S. Arzeniego g.[lobalizacja] oznacza przesunięcie procesu integracji stopień wyżej, ponad i poza zwykta wspólzależność. Jej następstwem staje się stapianie gospodarek narodowych w jedna funkcjonalna całość. H. Gomez Buendia nie definiując globalizacji, wskazuje jednocześnie na najistotniejsze zmienne, określając złożoność materii, jaka sktada się na to zjawisko. Przede wszystkim na państwo, które wciaż odgrywa w nim ważna rolę, na instytucje międzynarodowe wciąz obecne $w$ globalizujacym się świecie, na skale wspólnych problemów i możliwości ich rozwiązywania globalnie, ale też lokalnie, na wielowymiarowość procesów, jakie generuje, na zjawiska wzmacniajace g. [lobalizacje,] ale też na wektory i procesy wzmacniajace fragmentaryzację $i$ regionalizacje (...). Niezależnie wszakże od różnic dotyczacych genezy zjawiska nie ulega wątpliwości, że jest ono silnie związane z technologicznymi, cywilizacyjnymi, kulturowymi i politycznymi wyzwaniami 2 pol. XX wieku (...). Proces globalizacji obejmuje przede wszystkim handel, kulture i bezpieczeństwo (...). Najgłębiej i najbardziej całościowo obejmuje wymianę i handel w skali globalnej, w mniejszym stopniu sferę kultury, w jeszcze mniejszym bezpieczeństwo międzynarodowe (...). Spośród znanych koncepcji tego typu wskazać jednak można na teorię globalnej wioski H. M. McLuhana, ideę wspólnej kultury Q. Wrighta czy koncepcję kultury uniwersalnej W. Coplina [Żmigrodzki, 2010, s. 108-109]. 
się Amerykaninem [s. 41]. Popularna encyklopedia mass mediów określa natomiast to pojęcie jako proces przepływu wzorów $i$ wartości kulturowych oraz stylu życia typowego dla społeczeństwa amerykańskiego do reszty świata [s. 20]. W dalszej części definicji autorzy również wskazują na ścisły związek globalizacji i amerykanizacji, a także na istotną rolę mediów w pogłębianiu się obu procesów:

Głównym nośnikiem a.[merykanizacji] jest — rozpowszechniona za pomocą mass mediów - kultura popularna. W tym kontekście podaje się przykłady amerykańskich stacji telewizyjnych CNN i MTV, których przekaz dociera do niemal wszystkich społeczeństw.

Autorzy Stownika politologii [s. 10] podkreślają natomiast, iż

[w]raz z pojawieniem się Stanów Zjednoczonych jako dominującej ekonomicznie, militarnie i politycznie siły świata, pojęcie „Ameryka” zaczęło być kojarzone z agresywnym promowaniem interesów USA poprzez działania ekonomiczne i prowadzoną politykę zagraniczną.

Z procesami globalizacji i amerykanizacji wiąże się także szereg zagrożeń. W tym kontekście warto zacytować inny fragment Słownika politologii [s. 179]:

Globalizacja stawia pytanie, jak potoczą się dalsze losy demokracji i jej mechanizmów w warunkach ubóstwa wielu milionów ludzi, bezrobocia, ograniczonego dostępu wielu milionów osób do oświaty i osiągnięć nauki, wzrostu terroryzmu międzynarodowego i rozprzestrzeniania się broni masowego rażenia, problemów ekologii?

$\mathrm{Na}$ zagrożenia związane z procesem globalizacji oraz negatywny wpływ amerykanizacji na rozwój kultury i wrażliwość jej odbiorców wskazuje w swej twórczości współczesna pisarka austriacka Kathrin Röggla. Mieszkająca od 1992 r. w Berlinie autorka odnosi się z dystansem do otaczającej rzeczywistości. W swej prozie często ukazuje życie stolicy Niemiec, m.in. w Irres Wetter (Dziwna pogoda) ${ }^{2}$ z 2002 roku. Pisarka debiutowała w Austrii w 1988 roku. Zyskała sławę dzięki wydaniu w 1995 r. zbioru felietonów Niemand lacht rückwärts (Nikt nie śmieje się wspak). Od roku 2002 pisze również sztuki teatralne, które są wystawiane na wiodących scenach niemieckich i austriackich teatrów. Prapremiera jej ostatniego dotychczas dramatu Kinderkriegen (Posiadanie dzieci) odbyła się 12 V 2012 roku w monachijskim Residenztheater. Sztuka jest wystawiana na tej scenie również w roku 2013. W latach 1999-2012 rozgłośnie Bayerischer Rundfunk oraz DRS wyemitowały 16 słuchowisk autorstwa Kathrin Röggli. Pisarka otrzymała kilkanaście nagród literackich, m.in. Italo-Svevo-Preis (2001) i Arthur-Schnitzler-Preis (2012). Do marca 2013 roku włącznie opublikowała sześć powieści, tom opowiadań, liczne sztuki teatralne, a także felietony i inne utwory pisane prozą oraz jeden hipertekst. 7 marca 2013 roku ukazał się zbiór esejów i dramatów autorki pt. besser wäre: keine. 18 listopada 2012 roku telewizja ZDF wyemitowała pierwszy film w reżyserii Kathrin Röggli³ . Obecnie autorka pracuje nad tomem prozy Deregulierung.

${ }^{2}$ Wszystkie tłumaczenia tytułów i cytatów obcojęzycznych, jeśli nie zaznaczono inaczej, pochodzą ode mnie [E. W.-O.].

${ }^{3}$ Bewegliche Zukunft, steigende Katastrophe. Eine Reise ins Risikomanagement, ZDF 2012. 
W swojej twórczości pisarka podejmuje kwestie istotne dla egzystencji współczesnego człowieka i rozwoju kultury. Przedstawia charakterystykę społeczeństwa niemieckiego, ze szczególnym uwzględnieniem roli kobiety oraz problemów młodego pokolenia. Charakteryzuje zawrotne tempo życia we współczesnym świecie, wskazując na zanik kontaktów międzyludzkich i uzależnienie od nowoczesnej techniki. W wybranych powieściach i dramatach ukazuje apokaliptyczne wizje związane z dewastacją środowiska naturalnego, a także podejmuje problem rekultywacji terenów poprzemysłowych. Autorka krytykuje ponadto tzw. voyeuryzm telewizyjny i dominację mediów w życiu codziennym tzw. przeciętnych ludzi. Do najważniejszych problemów poruszanych w twórczości pisarki należy także przedstawienie negatywnych następstw globalizacji i amerykanizacji kultury europejskiej.

Rozwój gospodarki na skalę światową oraz ekspansja ponadnarodowych korporacji znajdują szereg zwolenników w społeczeństwie o charakterze konsumpcyjnym. 30-latkowie ukazani w powieści Röggli Niemand lacht rückwärts są rozczarowani z powodu braku perspektyw zawodowych [s. 9]. Ich zdaniem, podejmowane przez młodych ludzi próby zmiany ich położenia skazane są z góry na niepowodzenie [Tamże, s. 37]. W większości swych dzieł autorka nie wspomina o ruchu alterglobalistów. Wyjątek stanowi dramat die unvermeidlichen (Nieuchronni), w którym jest mowa o demonstracji przeciwników międzynarodowej konferencji.

W felietonie Worst Case Scenario (Scenariusz najgorszy z możliwych) i dramacie worst case (Najgorszy przypadek) autorka krytykuje rozwój gospodarki industrialnej na skalę globalną. Ów proces postrzega jako zjawisko negatywne, zwłaszcza w kontekście dewastacji środowiska i nadmiernej eksploatacji bogactw naturalnych. Przyczyniają się one nie tylko do obniżenia jakości życia, ale także stwarzają zagrożenie dla zdrowia i egzystencji współczesnego człowieka [Röggla, 2009b, s. 45-46; por. Röggla, 2008b].

W dziele die alarmbereiten (Gotowi do alarmu) artystka prezentuje katastroficzny obraz świata na skraju zagłady ekologicznej. W powieści jest mowa o histerii wywołanej tzw. chorobą wściekłych krów (BSE), a także o efekcie cieplarnianym oraz jego tragicznych następstwach: huraganach i pożarach [Röggla, 2010a, s. 30, 33, 38]. Obrazy płonących lasów i chmur pyłu, kojarzących się z Apokalipsą lub zagładą atomową, występują także w dramacie worst case. W fake reports (Sfatszowane sprawozdania) słuchacze telefonujący do rozgłośni radiowej wyrażają lęk przed wyczerpaniem zapasów żywności i wody [s. 6]. Złagodzenie kontroli granicznej wobec obywateli państw Unii Europejskiej ułatwiło również rozwój zorganizowanej przestępczości. Bohaterowie fake reports obawiają się zastosowania przez terrorystów broni biologicznej, zatrucia produktów spożywczych lub otrzymania pocztą przesyłki zawierającej śmiertelny wirus [Tamże, s. 8]. Poczucie zagrożenia wzmaga się $\mathrm{z}$ uwagi na doniesienia $\mathrm{w}$ mediach dotyczące kolejnych zamachów i katastrofy ekologicznej. W fake reports jeden z rozmówców przyznaje, iż zadzwonił do rozgłośni, aby się upewnić, czy jeszcze istnieje [s. 35]. O ogromnej dewastacji środowiska naturalnego w wyniku rozwoju cywilizacji przemysłowej świadczy fenomen 
„turystyki katastrof”, przedstawiony w really ground zero (Prawdziwa strefa zero) i worst case [por. Röggla, 2001, s. 9; Röggla, 2008b, s. 3, 65].

Kathrin Röggla piętnuje również następstwa globalizacji związane z funkcjonowaniem mechanizmów wolnego rynku. W tym kontekście pisarka wskazuje na wahania cen ropy po zamachu na WTC, a także inne skutki wydarzeń 11 września 2001 roku dla rozwoju gospodarki, m.in. dla przemysłu lotniczego [por. Röggla, 2008, s. 9]. Autorka negatywnie ocenia następstwa globalizacji w sferze ekonomicznej i społecznej. Ów proces wiąże się bowiem z zagrożeniem utraty przez tzw. przeciętnych ludzi materialnych podstaw ich egzystencji w wyniku światowego kryzysu. Zagadnienie to przedstawia autorka m.in. w dziele draussen tobt die dunkelziffer (Na zewnatrz szaleje bankructwo). W Irres Wetter natomiast z biedniejszymi dzielnicami Berlina kontrastuje centrum miasta, gdzie młodzi Niemcy, zwani przez autorkę „Zwycięzcami [procesu] globalizacji”, przesiadują w modnych restauracjach popijając wino: ja, globalisierungsgewinner: man hätte das zwar nicht vermutet, aber sie existieren, mitten unter uns, man kann sie anfassen, man kann sie ansprechen, manchmal antworten sie auch (... $)^{4}$ [s. 43].

Artystkę cechuje dystans do przedstawicieli niemieckiego społeczeństwa. Na ich przykładzie pisarka ukazuje zmiany w obyczajowości Europejczyków, związane się z postępującą globalizacją i amerykanizacją. Przedstawia m.in. hołdowanie modzie jako wyraz uniformizacji prowadzącej do zaniku indywidualności. Zdaniem autorki, popularność artykułów produkowanych przez firmy, których siedziby często znajdują się w Stanach Zjednoczonych, świadczy o rosnącej dominacji amerykańskiej kultury masowej. W powieści Irres Wetter Röggla przedstawia grupę uczennic w butach na koturnach i strojach popularnej marki H\&M, słuchających muzyki zespołu Duft Punk [s. 93]. Jak stwierdza narrator, reprezentowany przez dziewczęta styl ubierania się niezwykle łatwo skopiować [por. Tamże]. Nastolatki marzą o tym, by zamieszkać na jednej z pięknych wysp, gdzie będą bez ustanku bawić się na imprezach typu rave [por. Tamże, s. 94]. Media o zasięgu globalnym wywierają destrukcyjny wpływ na obyczaje, propagując wzorce takiego zachowania. Młodzież stara się dostosować do trendów dotyczących wyglądu zewnętrznego, w tym szczupłej sylwetki. Jedna z bohaterek powieści Niemand lacht rückwärts cieszy się z konieczności utrzymywania diety ze względów zdrowotnych, ponieważ, jak twierdzi, dzięki pięknej figurze będzie dobrze prezentować się w trakcie wywiadu telewizyjnego [s. 105]. Programy i audycje nagrywane w USA bywają popularyzowane w Europie przez lokalne spółki amerykańskich nadawców, m.in. CNN International, CNBC Europe i Fox Channel. W tym kontekście należy interpretować uwagę jednej z postaci dramatu fake reports dotyczącą, ,amerykańskiej hegemonii” [s. 28]. Inny bohater tego utworu wspomina o oglądaniu wiadomości CNN [Tamże, s. 18]. Recepcja programów i audycji nagrywanych w Stanach Zjednoczonych sprzyja pogłębieniu amerykani-

4 Tak, zwycięzcy [procesu] globalizacji: wprawdzie nikt by tego nie przypuszczal, ale oni istnieja, [sa] pośród nas, można do nich zagadać, czasem té̇ odpowiedza (...). 
zacji kultury m.in. w Niemczech. Telewizja prezentuje zwyczaje charakterystyczne dla mieszkańców USA, przenoszone następnie na grunt europejski. Media propagują również specyficzny styl życia, którego nieodłącznym elementem jest koncentracja na wartościach materialnych. Szczególnie w kręgach młodzieżowych coraz bardziej popularna staje się manifestacja symboli statusu. W Irres Wetter autorka przedstawia „nowobogackich”, którzy chwalą się wyposażeniem swoich aut: fahren sie vorbei in ihren sportwagen, in ihren kombis und mercedes und drehen die musik ganz laut auf $(\ldots)^{5}$ [s. 54]. Przejawem wpływu globalizacji na zwyczaje w Europie jest także zachowanie przedstawicieli subkultur młodzieżowych z różnych krajów w trakcie berlińskiej love parade: słuchanie muzyki punk i techno, tańczenie pogo, niekiedy — zażywanie narkotyków [por. Tamże, s. 79-80, 86].

Procesy globalizacji i amerykanizacji mają również wpływ na życie polityczne. W Europie często powiela się wzorce prezentowane przez media, dotyczące m.in. stylu prowadzenia kampanii wyborczych w USA i przygotowania publicznych debat. W powieści really ground zero autorka cytuje pełne demagogii przemówienia w Kongresie Stanów Zjednoczonych [s. 30-34]. Röggla piętnuje postępowanie polityków, którzy wykorzystują żałobę narodową, aby zwiększyć swe szanse u wyborców [Tamże]. Pisarka z dystansem odnosi się także do relacji telewizyjnych prezentujących uczczenie pamięci ofiar zamachu na WTC minutą ciszy: sich die schweigenden leute ansehen, d.h. hier hauptsächlich herrn bush beim schweigen zusehen ${ }^{6}$ [Röggla, 2008a, s. 14; por. Röggla, 2001, s. 38]. Röggla poddaje w wątpliwość przejmowanie na grunt europejski amerykańskich wzorców dotyczących kreowania w mediach wizerunku polityków. Cytowane przez autorkę przemówienia osób sprawujących funkcje publiczne świadczą o rosnącym militaryzmie: po zamachu na WTC usprawiedliwia się użycie siły bojowej armii USA w walce z terroryzmem. Globalizacja wiąże się z niebezpieczeństwem przeniesienia podobnych tendencji na grunt europejski.

W really ground zero Kathrin Röggla krytykuje ponadto wykorzystywanie wydarzeń 11 września 2001 roku dla celów komercyjnych, m.in. sprzedaż maskotek [por. Röggla, 2001, s. 18]. Autorka przedstawia także w swej twórczości reakcje niemieckiej opinii publicznej na wieść o zamachu na WTC [Röggla, 2001, s. 62; Röggla, 2008a, s. 15-16]. Bohaterowie fake reports są przekonani o tym, iż jedynie amerykańska telewizja wywiera destrukcyjny wpływ na widzów: lieber einfache menschen aus dem deutschen fernsehen werden. ein deutsches fernsehen gebe immer ein stabileres sicherheitsgefühl her als ein amerikanisches, soviel steht fest ${ }^{7}$ [s. 9]. Słowami postaci dramatu autorka krytykuje relacjonowanie zamachu na WTC „na żywo”, tj. nadawanie tzw. breaking news. Jeden z bohaterów utworu stwierdza: jedenfalls, es gebe gren-

5 Przejeżdzają obok w swoich sportowych wozach i rozkręcają muzykę na cały regulator (...).

${ }^{6}$ Oglądać milczących ludzi, tzn. tu głównie milczącego pana Busha (...).

${ }^{7}$ Lepiej zostać zwyktymi ludźmi z niemieckiej telewizji. Niemiecka telewizja zapewnia bardziej stabilne poczucie bezpieczeństwa niż amerykańska, to jest pewne. 
zen, über die solle man auf keinen fall hinausgehen ${ }^{8}$ [s. 16]. Pisarka uważa, że media nie powinny ukazywać drastycznych scen, ponieważ emitowane nagrania na zawsze pozostaną w pamięci widzów na całym świecie [por. Röggla, 2008a, s. 35]. Wraz z relacjami z tzw. „strefy zero”, świat obiegły zdjęcia dokumentujące żałobę narodową w USA oraz manifestowanie uczuć patriotycznych. Autentyczne fotografie ulic przystrojonych flagami autorka opublikowała również w powieści really ground zero [s. 107]. W dramacie fake reports słuchacze audycji radiowej wypowiadają się na antenie na temat nabożeństwa ku czci ofiar zamachu [s. 14; por. Röggla, 2001, s. 42-44]. Röggla podkreśla, iż celebrowanie w Stanach Zjednoczonych żałoby narodowej wydaje się przesadne zarówno Niemcom, jak i niektórym Amerykanom.

Obserwacja życia mieszkańców Nowego Jorku skłania artystkę do refleksji na temat różnic między USA a Europą, której mieszkańców cechuje, zdaniem pisarki, kulturowa odrębność. Owocem przemyśleń autorki w trakcie jej 7-tygodniowej podróży do Japonii jest utwór tokio, rückwärtstagebuch (Tokio, pamiętnik pisany wstecz). Pierwszą część dzieła stanowi pamiętnik, a część druga to komiks, który nawiązuje do stylistyki powieści wizualnej (visual novel) i japońskich filmów z gatunku anime. Zarówno tekst, jak i ilustracje Olivera Grajevskiego ukazują postać autorki zagubionej w wielkiej metropolii. W zetknięciu z obcą kulturą pisarka doświadcza zjawiska culture clash, podobnie jak bohaterowie filmu Lost In Translation (Między słowami) Sofii Coppoli (2003).

W swej twórczości Röggla wyraża przekonanie, że mentalność mieszkańców USA różni się od usposobienia Europejczyków. Jeden z bohaterów fake reports stwierdza jednak, iż w Stanach Zjednoczonych wkrótce zabraknie ,wiecznych optymistów" [por. Röggla, 2008a, s. 26]. W 6 scenie dramatu anonimowy polityk niemiecki denerwuje się z powodu tego, (...) jak dalece amerykańscy Amerykanie sq amerykańscy (wie die amerikanischen amerikaner amerikanisch sind) [Tamże, s. 29]. Z dystansem traktuje się też turystów z USA nagrywających w trakcie podróży filmy video [por. Röggla, 2004a, s. 117]. Jedna z postaci dramatu fake reports zadaje pytanie, czy Europejczycy nadal chcą być bardziej amerykańscy niż Amerykanie (amerikanischer als die amerikaner) [s. 27]. Bohater dochodzi do wniosku: die amerikaner sind gar nicht so schnell. die amerikaner sind ja gar nicht so billig. die amerikaner sind ja gar nicht so deutsch ${ }^{9}$ [Tamże, s. 27].

Dowodem na rosnącą amerykanizację kultury europejskiej jest również, zdaniem pisarki, powszechne stosowanie anglicyzmów. Występują one w tytułach dzieł Röggli bądź ich rozdziałów, w dialogach i narracji, w nazwach miejsc i postaci oraz w didaskaliach. Są to zwykle pojedyncze słowa i wyrażenia, na przykład sorry ('przepraszam'). Zdarzają się także tzw. zdania wtrącone. Na uwagę zasługują ciekawe złożenia, a także zabawy słowem, m.in. przykłady aliteracji [por. Kremer, 2008, s. 120-122]. W po-

${ }^{8}$ W każdym razie, sa granice, których za żadne skarby nie wolno przekroczyć.

9 Amerykanie nie sa wcale tacy szybcy. Amerykanie wcale nie sa tacy tani. Amerykanie wcale nie sa tacy niemieccy. 
wieści Irres Wetter autorka podkreśla fakt, że uczestnicy love parade porozumiewają się w stolicy Niemiec w języku angielskim: da hilft nur noch eines, broken englisch: please excuse me, das ist das einzige, was hier noch greift ${ }^{10}$ [s. 6]. Pisarka nawiązuje ponadto do zagadnienia rosnącej amerykanizacji obywateli państw postkomunistycznych: im osten redet man ja praktisch nur noch englisch, da fängt niemand etwas anderes an. das ist unsere muttersprache (... ${ }^{11}$ [Tamże, s. 6]. Mimo porozumiewania się w języku angielskim, między uczestnikami love parade nie zanikają różnice społeczne i kulturowe. Narrator stwierdza: uns trennen welten (Dziela nas światy) [Tamże, s. 8]. W dalszej części główna bohaterka zachęca rozmówców, aby wyobrazili sobie, iż potrafiliby mówić tylko „łamanym angielskim” [Tamże, s. 104].

Kathrin Röggla często przedstawia w swej twórczości kontrowersyjne sytuacje zmuszając czytelników do refleksji nad zagadnieniem tożsamości i odrębności kulturowej. Krytyka nadużywania zapożyczeń z języka angielskiego występuje także w powieści wir schlafen nich (Nie sypiamy) i opartym na niej dramacie pod tym samym tytułem [por. Röggla, 2004b; Röggla, 2004c]. Wprowadzenie anglicyzmów służy tu charakterystyce hermetycznego środowiska pracowników jednej z wielkomiejskich korporacji, określanych w recenzjach obu dzieł jako zombies [por. Siegel, 2010, s. 236]. Autorka krytykuje nadużywanie zwrotów obcojęzycznych w mowie potocznej. $Z$ dystansem odnosi się także do stereotypu dotyczącego amerykańskiej wiary w sukces. Pisarka ukazuje pracoholików, którzy, na wzór amerykańskich yuppies, koncentrują się wyłącznie na karierze kosztem życia osobistego. Ów wątek występuje ponadto w powieści really ground zero i dramacie fake reports. Wraz z amerykanizacją obyczajów postępuje oderwanie jednostki od więzów społecznych. W fake reports, a także w jednym $\mathrm{z}$ esejów Röggli, jest mowa o człowieku pracującym w WTC, który, mimo pożaru, nie przerwał pracy przy swym biurku [por. Röggla, 2008a, s. 33; Röggla, 2009a, s. 22]. Autorka zmusza czytelnika do refleksji nad tym, czy bezkrytyczne naśladowanie amerykańskich wzorców ma sens.

Do negatywnych następstw globalizacji i rozwoju cywilizacji przemysłowej należy także nieodwracalna degradacja środowiska naturalnego. W utworze really ground zero pisarka ukazuje niemal wymarłe, zaniedbane obszary postindustrialne w USA [s. 63]. Globalizacja dotyka również sfery obyczajów. Bywa związana z rosnącą komercjalizacją życia codziennego. Proces ten zaczyna się bardzo wcześnie: autorka opisuje w Irres Wetter chłopca bawiącego się co wieczór, jak tysiące jego rówieśników, klockami Lego i czytającego przed snem komiksy [s. 72]. Dowodem postępującej globalizacji są również nawiązania do tradycji kulinarnych innych krajów. W berlińskich kawiarniach podaje się na przykład włoski deser o nazwie tiramisu [Tamże, s. 86].

10 Tu pomaga tylko jedno, broken English: please, excuse me, to jedyne, co tu jeszcze działa.

${ }^{11}$ Na Wschodzie mówi się praktycznie tylko po angielsku, tu nawet nikt nic innego nie próbuje to jest nasz język ojczysty (...). 
W swojej twórczości austriacka autorka podkreśla, iż globalizacja postępuje dzięki zdobyczom techniki. Uzależnienie od nich pisarka ukazuje jednak w krytycznym świetle [por. Röggla, 2002, s. 72]. Bohaterowie prozy Röggli chętnie korzystają z komputerów lub telefonów komórkowych i coraz rzadziej znajdują czas na to, by spotkać się ze swymi znajomymi osobiście [Tamże, s. 107]. Młoda kobieta w powieści die alarmbereiten ogranicza swe kontakty ze światem zewnętrznym do rozmów telefonicznych [s. 47]. Pod wpływem przerażających relacji medialnych zaczyna ona mieć objawy agorafobii. Globalizacja dokonuje się jednak nie tylko dzięki telefonii komórkowej, telewizji, rozgłośniom radiowym czy Internetowi. Ogromny wpływ na kulturę europejską wywiera również, zdaniem pisarki, recepcja sztuki filmowej. W Irres Wetter narrator wspomina o dziełach Lola rennt (Biegnij, Lola, biegnij, 1998) oraz Brassed off (Orkiestra, 1996), a wizerunek Anioła kojarzy mu się z nazwiskiem Nicolasa Cage'a [por. s. 74]. Chodzi tu zapewne o amerykańsko-niemiecką koprodukcję City of Angels (Miasto Aniołów, 1998). Zdaniem Röggli, kino służy amerykańskiej paternalizacji, zwłaszcza, iż premiery wielkich produkcji często odbywają się w USA i Europie w tym samym czasie. Autorka jest przeciwna dystrybucji filmów z gatunku katastroficznych (m.in. Airport, 1970) oraz dzieł zawierających szczególnie brutalne sceny [por. Röggla, 2009a, s. 45-46]. Zdaniem pisarki, ich recepcja przyczynia się do tłumienia wrażliwości widzów.

Reasumując, Kathrin Röggla wskazuje w swej twórczości na negatywne skutki globalizacji. Autorka odnosi się krytycznie również do amerykanizacji kultury europejskiej, pogłębiającej się za sprawą rozwijającej się techniki i mediów. Pisarka negatywnie ocenia skutki globalizacji, której efekty determinują również życie codzienne tzw. przeciętnych ludzi. Artystka piętnuje destrukcyjną działalność przedstawicieli państw uprzemysłowionych, polegającą na nadmiernej eksploatacji zasobów naturalnych, a także inne następstwa globalizacji w sferze ekonomicznej, społecznej i polityce. Autorka występuje w swych dziełach w obronie kulturowej odrębności narodów Europy, krytykując zarówno amerykański paternalizm, jak i propagowanie przez mass media tzw. „kultury niskiej”, której dominacja również może doprowadzić ludzkość do Apokalipsy. 


\section{AnalizoWane UTWORY}

RöGGLA K., 2001, really ground zero, Frankfurt am Main.

-, 2002, Irres Wetter, Frankfurt am Main.

-, 2004a, Niemand lacht rückwärts, Frankfurt am Main.

—, 2004b, wir schlafen nicht [Roman], Frankfurt am Main.

—, 2004c, wir schlafen nicht [Theaterstück], „Theater heute“, nr 3, s. 59-67.

—, 2006a, draussen tobt die dunkelziffer [Hörspielfassung], Basel i in.

—, 2007, Abrauschen, Frankfurt am Main.

—, 2008a, fake reports [Manuskript], Frankfurt am Main.

—, 2008b, worst case [Manuskript], Frankfurt am Main.

-, 2009a, Gespensterarbeit, Krisenmanagement und Weltmarktfiktion, Wien.

—, 2009b, Worst Case Scenario, „Die Zeit”, 05.03.2009, s. 45-46.

—, 2010, die alarmbereiten, Frankfurt am Main.

—, 2011, die unvermeidlichen [Aufführungsmaterial], Mannheim.

—, 2012, Worst Case [Artikel] [online] [dostęp 27.04.2012] www.dtver.de.

RöGgla K., GRajevski O., 2009c, tokio, rückwärtstagebuch, Nürnberg.

\section{Bibliografia}

AREND I., 2002, Ziemlich irre Perspektive. Realer Raum. Kathrin Rögglas literarisches

New-York-Protokoll nach dem 11. September, „Freitag“ 2002, nr 3, s. 14.

BŁAchNio A. (red.), 2009, Globalizacja a jednostka, Bygdoszcz.

GruBer P. C., ZAPOTOCZKy K. (red.), 1999, Globalisierung versus Demokratie?, Linz. IvaNOVIC Ch., 2006, Bewegliche Katastrophe, stagnierende Bilder. Mediale Verschiebungen in Kathrin Rögglas «really ground zero», „Kultur \& Gespenster” 2006, nr 2, s. 108-117.

JАско J. F., 2008, Globalizacja a różnice kulturowe. Przyczynek do metodologii badań międzykulturowych [w:] Globalizacja - nieznośne podobieństwo? Świat i jego instytucje w procesie uniformizacji, Krauz-Moser B., Borowiec P. (red.), Kraków, s. 261-277.

Kremer Ch., 2008, Milieu und Performativität. Deutsche Gegenwartsprosa von John Düffel, Georg M. Oswald und Kathrin Röggla, Marburg.

Politologia. Przewodnik encyklopedyczny, 2008, pod red. Mikusińska A., Warszawa. Popularna encyklopedia mass mediów, 1999, pod red. Skrzypczak J., Poznań.

Robertson D., 2009, Słownik polityki, tłum. Dera M., Młynarz M., Polak G., Wonicki R., Warszawa.

SiEgEL E.M., 2010, Gewaltwirtschaft? Im Inneren der Funktion (kathrin röggla)

[w:] Gewalt in der Moderne, Siegel E. M., Marburg.

Stownik politologii, 2008, pod red. Walickiej B., Warszawa.

Stownik wyrazów obcych PWN, 2002, pod red. Sobol E., Warszawa.

Szczakowski Z. J., 2010, Meandry i wyzwania procesu globalizacji, Łódź. 
WaleszCZAK Z., 2005, Globalisierung als neue Sozialfrage, Bayreuth.

Wojno-OwCZARSKa E., 2006, Der Typus der modernen Frau in Kathrin Rögglas Drama «wir schlafen nicht», ,Studia Niemcoznawcze/Studien zur Deutschkunde”, t. 33, Warszawa, s. 351-360.

—, 2011, Katastrofa 11 września 2001 roku w powieści Kathrin Röggli »really ground zero«, „Studia Niemcoznawcze/Studien zur Deutschkunde”, t. 48, s. 277-292.

—, 2012,,, Wirleben in restaurativen Zeiten “. Zu Kathrin Rögglas ,, unvermeidlichen “, „Studia Niemcoznawcze/Studien zur Deutschkunde”, t. 50, s. 391-402.

-, 2012, 11 września 2001 roku oraz 11 marca 2004 roku w utworach , really ground zero” Kathrin Röggli i „Madryt, 11 marca” Zuzanny Jakubowskiej, „Studia Niemcoznawcze/Studien zur Deutschkunde", t. 50, s. 433-445.

ŻMigrodzki M. (red.), 2010, Encyklopedia politologii, $t$. V Stosunki miedzynarodowe, pod red. Łoś-Nowak T. i Florczak A., Warszawa.

—, 2011, Encyklopedia politologii, t. IV Myśl społeczna i ruchy polityczne współczesnego świata, pod red Marczewskiej-Rytko. M. i Olszewskiego E., Warszawa.

ŻuKrowsKa K. (red.), 2012, Harnessing globalization, czyli ujarzmianie globalizacji, Warszawa. 